原著

\author{
ドパミンアゴニストからゾニサミドへの切り替えによる \\ パーキンソン病患者の精神症状及び運動症状への影響
}

阿部＼cjkstart隆志1)* 丸山 秀德2)

\begin{abstract}
要旨：ドパミンアゴニスト（dopamine agonist，以下 DA と略記）が原因で幻覚・妄想を発現したと考えられ るレボドパ服用中のパーキンンン病（Parkinson's disease, 以下 PD と略記）患者 11 例に対し, DA 隇量・中止 と同時にゾニサミドを新規投与し, 精神・運動症状への影響を評価した. その結果, MDS-UPDRS Part 1.2 (幻 覚と精神症状）及びPart 3 （運動症状）のベースラインから 12 週後のスコア变化量（LS Mean \pm SE）はそれ ぞれ-2.4 $\pm 0.2,-5.1 \pm 0.9$ であり，共に有意なスコア低下が認められた．以上の結果から，幻覚・妄想の 発現・増悪への対処としてDA の減量・中止した時のゾニサミド追加療法は, PD 患者の精神・運動症状のコント ロールに有用な戦略になる可能性が考えられた.
\end{abstract}

（臨床神経 2021;00:000-000）

Key words：パーキンソン病, ゾニサミド, ドパミンアゴニスト, 幻覚・妄想, 運動症状

1. 前文

パーキンソン病 (Parkinson's disease, 以下 PD と略記) は, 中脳黑質ドパミン神経の変性・脱落を特徴とする神経変 性疾患であり，運動緩慢，振戦，筋強剛等の運動症状を呈す る ${ }^{1)}$. 更に, 幻覚・妄想, うつ症状, アパシー, 不安, 睡眠 障害, 自律神経障害等の非運動症状も併発し ${ }^{122}$, 運動症状と 併せて患者・介護者の QOL 低下の要因となるため ${ }^{3)}$, 運動症 状の治療と並行して非運動症状への対処も必要となる.

$\mathrm{PD}$ の標準的な治療はドパミン補充療法であり, 今日で もその中心はレボドパ含有製剤（以下レボドパと略記）で あるが1)，レボドパは疾患の進行に伴い wearing-off やジスキ ネジア等の運動合併症を発現するため, レボドパのみでは運 動症状がコントロール困難となる ${ }^{4)}$ ，そのため，ドパミンア ゴニスト (dopamine agonist, 以下 DA と略記), catechol-Omethyltransferase 阻害剂, Monoamine oxidase B (MAOB) 阻 害剤, ゾニサミド，イストラデフィリンの追加が $\mathrm{PD}$ 診療ガ イドライン 2018 で推奨されている ${ }^{1)}$.これらのうち, 同ガイ ドライン治療アルゴリズム 1) で上位に記載されているのが
DA であるが, 特に高齢者においては DA の有害事象として 報告がある日中過眠, 突発性睡眠, 幻覚・妄想が問題になる 場合があり ${ }^{5}$ ，副作用の発現に注意しながら使用することと なる ${ }^{1)}$.

幻覚・妄想等の精神症状は, PD 自体に起因することに加 え, 治療に用いられる薬剤でも誘発されることがある。その ため, 幻覚・妄想が発現した患者に扔いては, 最後に追加し た抗 PD 薬の減量・中止, それでも改善しない場合は, 他の 抗 PD 薬を順に減量・中止していくが 1), それにより運動症 状の悪化, 及び日常生活動作 (activity of daily living, 以下 ADL と略記）の低下が懸念されるため, 患者ごとに調整が必 要となる。幻覚・妄想は認知の低下により誘発されることも あるため, 抗認知症薬の追加も考慮し, それでも幻覚・妄想 の軽減が難しいときは抗精神病薬が使用されることがあるが, ドパミン D2 受容体遮断作用に基づく運動症状の悪化の可能 性がある。このように, 幻覚・妄想を発現したPD 患者に対 し, 運動症状のコンロトール及びADL を維持しつつ, 幻覚・ 妄想に対処することが PD の治療課題の一つである。

ゾニサミドは PD 及びレビー小体型認知症（dementia with

*Corresponding author: 医療法人あべ神経内科クリニック〔̄ 020-0878 盛岡市有町 6-6 熊長ビル 1F〕

1) 医療法人あべ神経内科クリニック

2) 大日本住友製薬株式会社メディカルアフェアーズ部

(Received October 6, 2020; Accepted March 1, 2021; Published online in J-STAGE on June 18, 2021)

doi: 10.5692/clinicalneurol.cn-001554

Supplementary data for this article is available in our online journal. Official Website http://www.neurology-jp.org/Journal/cgi-bin/journal.cgi

J-STAGE https://www.jstage.jst.go.jp/browse/clinicalneurol 
Lewy bodies，以下 DLB と略記）を対象とした一連の治験 6) 10) を経て, $25 \mathrm{mg}$ が PD の運動症状及び DLB のパーキンソニズ ムの治療薬として, $50 \mathrm{mg}$ が PD の wearing-off の治療薬とし て日本で承認されている。ゾニサミドの抗パーキンソン作用 については，ドパミン系作用（ドパミン合成促進作用 ${ }^{11)}$, MAOB 阻害作用 ${ }^{12)}$, Tyrosine hydroxylase 活性促進作用 ${ }^{13)}$ ), 及び非ドパミン系作用 $\left(\mathrm{T}\right.$ type $\mathrm{Ca}^{2+}$ channel 阻害作用 ${ }^{14) 15)}$, $\mathrm{Na}^{+}$channel 阻害作用 $\left.{ }^{16}\right) ， \delta 1$ agonist 様作用を通じた大脳基底 核の間接路抑制作用 ${ }^{17)}$ ) 等の複数のメカニズムが報告されて いる。また、ゾニサミドの PD を対象とした治験 7)8 幻覚・妄想の副作用はプラセボの発現頻度と大きく変わらな いことが報告されているが，これはゾニサミドの抗 PD 薬と してのメカニズムが, ドパミン系作用だけでなく, 幻覚・妄 想の発現リスクが少ないと考えられる非ドパミン系作用もあ ることと関係しているのかもしれない，一方，幻覚・妄想を 有するPD 患者を対象とした研究結果はなく，既に発現して いる幻覚・妄想へのゾニサミドの影響は不明である。

そこで著者らは，「ゾニサミドの追加は，DAの減量・中止 による運動症状の悪化及び ADL の低下を防ぎ，な掞かつ幻 覚・妄想を軽減できる」との仮説を立て，本研究で，DAに より幻覚・妄想が発現している $(\mathrm{DA} か ゙ \mathrm{PD}$ 診療ガイドライン 2018 ${ }^{1)}$ の幻覚・妄想の治療アルゴリズムに打ける「直近にく わえた薬物」に該当する）と考えられるレボドパ服用中の PD 患者に対して，DA 減量・中止と同時にゾニサミド追加を行っ た際の精神症状, 及び運動症状への影響を探索的に評価した。

\section{2. 対象・方法}

\section{1 研究対象者}

本研究の対象は，全ての選択基準を満たし，全ての除外基 準に抵触しない PD 患者とした，選択基準は，(1）レボドパ 及び DA を服用中で，幻覚，妄想あるいはその両方を有する (Movement Disorder Society-Sponsored Revision of the Unified. Parkinson's Disease Rating Scale [MDS-UPDRS］Part 1.2 [幻 覚と精神症状］スコアが 2 以上)，（2）30 歳以上，（3）研究 参加への本人の自由意思による文書同意とした。 なお，幻覚・ 妄想に関する選択基準を MDS-UPDRS Part 1.2 スコアが 2 以 上とし，その症状が軽度の患者も対象としたが，これらの患 者は疾患進行に伴う薬剤の増量等により日常生活に影響を与 えるレベルである中等度以上に症状が発展するリスクが高い と考えられるため，PD 患者の幻覚・妄想を長期にわたるコ ントロールには, 症状が軽度の段階から対処する必要がある と考えたからである。除外基準は，(1) 研究開始前 6 力月以 内のゾニサミド服用歴，(2) 認知機能障害 (Mini-Mental State Examination [MMSE，認知機能] スコアが 23 点以下)，(3) パーキンソニズムに対する外科的治療歴，（4）妊婦，妊娠の 可能性がある，あるいは授乳中の女性，(5) 本研究の対象と して不適との研究責任者等の判断した患者とした，登録期間 は 2016 年 11 月から 2018 年 6 月までとした。
2.2 研究デザイン, 併用禁止・制限療法

研究デザイン：試験薬はゾニサミドとし，承認された用法・ 用量 $(25 \mathrm{mg}$ あるいは $50 \mathrm{mg})$ で 12 週間経口投与した。ま た, DA は, 研究開始時（ゾニサミド投与開始時）から減量 又は中止し, 増量及び投与再開は禁止した。な㧍，DAの減 量のスピード, 及び DAを中止するか, 減量に留めるかは, 対象者の症状の状態に応じて主治医が判断することとした， 併用制限療法：他の抗 PD 薬，コリンエステラーゼ阻害薬及 び非定型抗精神病薬は, 研究開始 2 週間前から終了/中止時ま で用法・用量を一定とし，研究開始前から実施しているリハ ビリテーションは，内容を変更せずに継続した，併用禁止療 法：PD 外科的治療及び経頭蓋磁気刺激法は実施不可とし, $\mathrm{PD}$ 治療目的の抗コリン薬は併用禁止とした.

\section{3 評価項目}

主要評価項目は, MDS-UPDRS Part 1.2 及び Part 3 のベー スラインに対する 12 週後のスコア変化量とした。 副次的評 価項目は, MDS-UPDRS Part 1 (非運動症状), Part 2(ADL), Part 4（運動合併症）, Beck Depression Inventory-II（BDI-II, 抑うつ), Japanese version of the Epworth Sleepiness Scale (JESS，眠気)，MMSE，それぞれのベースラインに対する 12 週後のスコア変化量とした。また，その他の評価では，各運 動症状への影響として, 関連する MDS-UPDRS の下位項目 ${ }^{18)}$ を症状ごとに割り振り（振戦：2.10，3.15～3.18, 筋強剛： 3.3, 運動緩慢：3.4 3.8，3.14, 姿勢保持障害 - 歩行障害： 2.12 2.13，3.10 3.12), そのスコア变化量を評価した，安 全性評価項目は, 同意取得後から最終観察終了時までに発現 した（1）有害事象，（2）副作用とした。

\section{4 解析方法}

解析対象集団は Full analysis set（FAS）とし, 統計解析ソ フトウェアは, SAS ${ }^{\circledast}$ (SAS Institute Inc., Cary, NC, US） ver. 9.4 を使用した。

主要評価項目の解析は, MDS-UPDRS Part 1.2 及び Part 3 のベースラインに対するスコア変化量について, 時点を固定 効果, ベースラインを共変量とし, 繰り返し測定混合効果モ デル (mixed effects models for repeated measures) を用いて最 小二乗平均（least squares mean, 以下 LS mean と略記） \pm Standard Error（SE）を算出し, 有意差検定では有意水準を両 側 5\%とし，95\%信頼区間（confidence interval，以下 CI と略 記）及び $P$ 值を算出した，副次的評価項目及びその他の評価 は, 各評価項目のスコア変化量を主要評価項目と同様に解析 した.

本研究は,「ヘルシンキ宣言」に基づく倫理的原則, 研究計 画書を遵守し,「ICH-GCP ガイドライン」に準拠，「人を対象 とする医学系研究関倫理指針」に基づいて実施し, 研究対象 者から文書による同意を取得したままた，本研究は病院合同 倫理審査委員会の承認を得て実施した（管理番号： $14000050.20160916-4030$, 承認日：2016 年 9 月 16 日) (UMIN 試験 ID：UMIN000024859). 
Table 1 Patient characteristics.

\begin{tabular}{|c|c|c|}
\hline & \multicolumn{2}{|c|}{$N=11$} \\
\hline Age (years), mean $\pm \mathrm{SD}$ & $73.4 \pm 8.1$ & \\
\hline$\geq 65, \mathrm{n}, \%$ & 10 & $90.9 \%$ \\
\hline Gender, Male, n, \% & 1 & $9.1 \%$ \\
\hline Duration of Parkinson's disease (years), mean \pm SD & $7.98 \pm 6.35$ & $(N=10)$ \\
\hline Hoehn and Yahr Severity Score at on-time, mean \pm SD & $2.0 \pm 0.0$ & \\
\hline Wearing off, n, \% & 5 & $45.5 \%$ \\
\hline \multicolumn{3}{|l|}{ Combined medications, n, \% } \\
\hline Levodopa/DOPA-decarboxylase inhibitor & 11 & $100 \%$ \\
\hline Dopamine agonist (of which, dose reduction/cancellation) & $11(11)$ & $100 \%(100 \%)$ \\
\hline Ropinirole hydrochloride & $7(7)$ & $63.6 \%(63.6 \%)$ \\
\hline Rotigotine & $4(3)$ & $36.4 \%(27.3 \%)$ \\
\hline Pramipexole hydrochloride hydrate & $1(1)$ & $9.1 \%(9.1 \%)$ \\
\hline \multicolumn{3}{|l|}{ Other antiparkinsonian medications } \\
\hline Entacapone (including combination drugs) & 2 & $18.2 \%$ \\
\hline Istradefylline & 2 & $18.2 \%$ \\
\hline Selegiline hydrochloride & 1 & $9.1 \%$ \\
\hline \multicolumn{3}{|l|}{ Baseline score, mean $\pm \mathrm{SD}$} \\
\hline MDS-UPDRS Part 1 & $19.3 \pm 8.0$ & \\
\hline MDS-UPDRS Part 1.2 & $2.7 \pm 0.5$ & \\
\hline MDS-UPDRS Part 2 & $18.2 \pm 12.8$ & \\
\hline MDS-UPDRS Part 3 & $31.5 \pm 7.2$ & \\
\hline MDS-UPDRS Part 4 & $1.7 \pm 2.1$ & \\
\hline \multicolumn{3}{|l|}{ Motor symptoms } \\
\hline Tremor & $5.8 \pm 2.9$ & \\
\hline Rigidity & $7.2 \pm 1.6$ & \\
\hline Bradykinesia & $15.5 \pm 3.3$ & \\
\hline PIGD & $4.5 \pm 3.6$ & \\
\hline BDI-II & $15.4 \pm 10.2$ & \\
\hline JESS & $10.1 \pm 7.3$ & \\
\hline MMSE & $27.0 \pm 1.2$ & \\
\hline
\end{tabular}

BDI-II, Beck Depression Inventory-II; JESS, Japanese version of the Epworth Sleepiness Scale; MDSUPDRS, Movement Disorder Society-sponsored revision of the Unified Parkinson's Disease Rating Scale; MMSE, Mini-Mental State Examination; PIGD, postural instability and gait disturbance; SD, standard deviation.

\section{3. 結果・成績}

\section{1 研究対象者}

本研究に 11 例が登録され，全例が研究を完了，FAS として 採用した、ゾニサミドの用量は，全例 $25 \mathrm{mg}$ であり，PD患 者の運動症状改善（DA の減量・中止による運動症状悪化一 の対処）を目的に $25 \mathrm{mg}$ を選択した. Table 1 に患者背景を示 す. 年齢（平均 \pm Standard Deviation $[\mathrm{SD}]$ ）は $73.4 \pm 8.1$ 歳, 65 歳以上は 10 例，男性は 1 例，PD 罹病期間（平均 $\pm \mathrm{SD})$ は $7.98 \pm 6.35$ 年であった。また, ベースライン MDS-UPDRS Part 1.2 及び Part 3 スコア（平均 \pm SD）は，それぞれ $2.7 \pm$
0.5, $31.5 \pm 7.2$ であった。減量・中止された DA は，ロピニ ロール塩酸塩 7 例, ロチゴチン 3 例, プラミペキソール 1 例 であり，12 週後には 5 例が投与中止， 6 例が減量であった (Table 1). 抗 PD 薬の併用状況は, レボドパ，DA 以外では, エンタカポン，イストラデフィリンが各 2 例，セレギリン塩 酸塩が 1 例であった。

\section{2 有効性評価}

主要評価項目である MDS-UPDRS Part 1.2 スコアは， 2 週 後よりベースラインに比して有意な低下を示し，更に 12 週 後まで低下した（Fig. 1).12 週後のスコア変化量（LS mean 


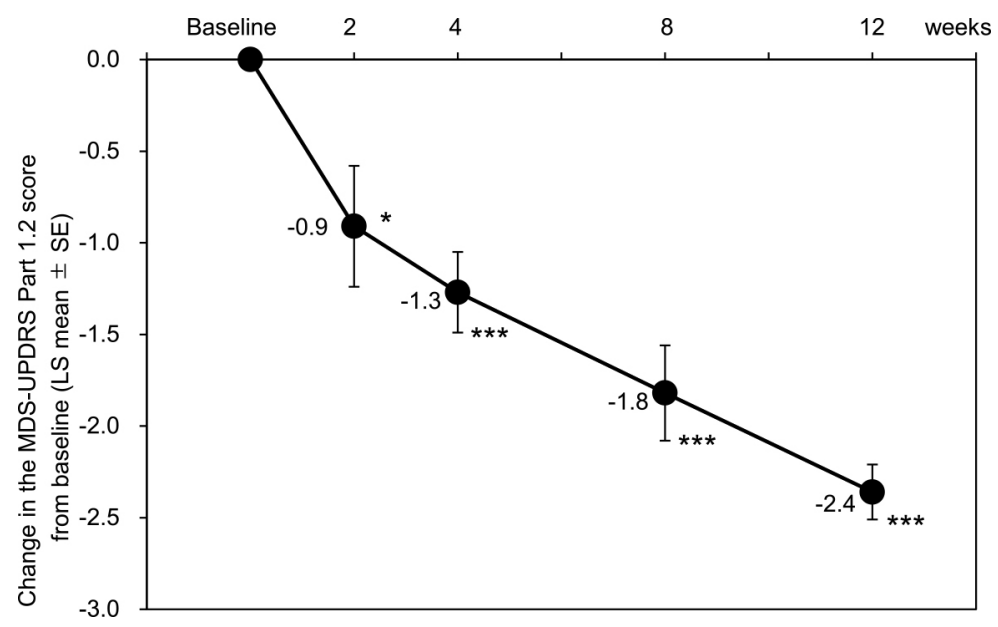

Fig. 1 Change in the MDS-UPDRS Part 1.2 score from baseline.

The MDS-UPDRS Part 1.2 (Hallucinations and Psychosis) score significantly decreased 2 weeks from baseline and continued to decrease until week 12 , suggesting that the patients experienced continued improvement in terms of hallucinations and psychological symptoms. *: $P<0.05$, ***: $P<0.001$ (vs. baseline) calculated with an MMRM.

LS mean, least squares mean; MDS-UPDRS, Movement Disorder Society-sponsored revision of the Unified Parkinson's Disease Rating Scale; MMRM, mixed-effect model for repeated measures; SE, standard error.

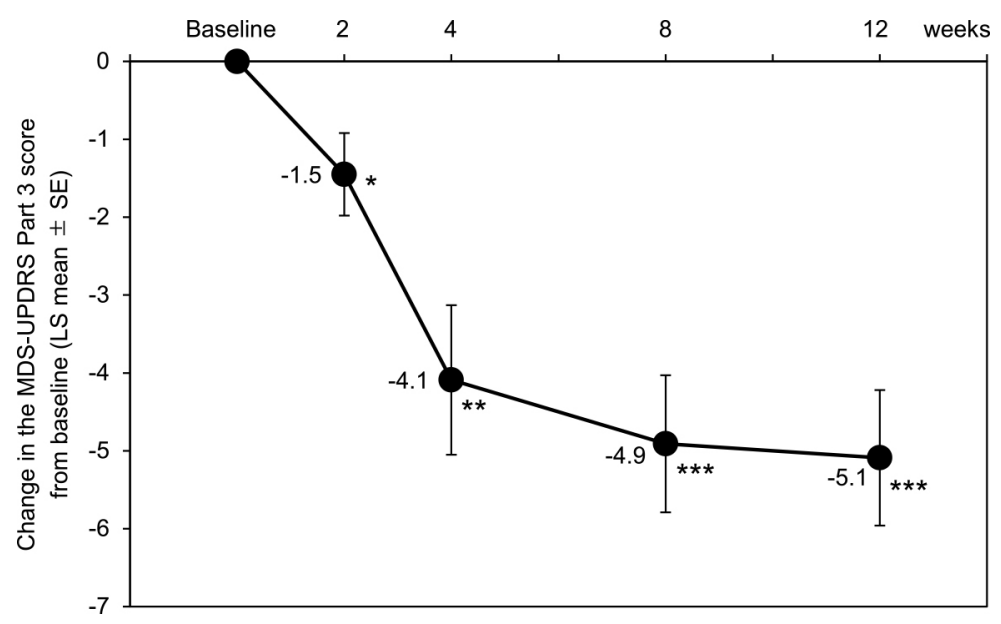

Fig. 2 Change in the MDS-UPDRS Part 3 total score from baseline.

The MDS-UPDRS Part 3 (Motor Examination) total score significantly decreased 2 weeks from baseline and continued to decrease until week 12 , suggesting that the patients experienced continued improvement in terms of motor symptoms. *: $P<0.05,{ }^{* *}: P<0.01$, ***: $P<0.001$ (vs. baseline) calculated with an MMRM. LS mean, least squares mean; MDS-UPDRS, Movement Disorder Society-sponsored revision of the Unified Parkinson's Disease Rating Scale; MMRM, mixed-effect model for repeated measures; SE, standard error.

$\pm \mathrm{SE})$ は $-2.4 \pm 0.2(95 \% \mathrm{CI}-2.7$ to $-2.0, \quad P<0.0001)$ で あり, ベースラインに比して有意にスコアが低下した.

他方の主要評価項目である MDS-UPDRS Part 3 スコアは, 2 週後よりベースラインに比して有意な低下を示し, 更に 12 週後まで低下した (Fig. 2). 12 週後のスコア変化量 (LS mean $\pm \mathrm{SE})$ は $-5.1 \pm 0.9(95 \% \mathrm{CI}-7.0$ to $-3.1, P=0.0002)$ で あり, ベースラインに比して有意にスコアが低下した。
各運動症状は, 振戦, 筋強剛, 運動緩慢, それぞれの 12 週後のスコアはベースラインに比して有意な低下を認め, 姿 勢保持障害・歩行障害スコアは有意な変化を示さなかった (Table 2).

MDS-UPDRS のその他のスコアは, Part 1 がベースライン に比して 12 週後に有意な低下を認め, Part 2, Part 4 は有意 な変化を示さなかった（Table 2). MDS-UPDRS の下位項目 
Table 2 Score changes at 12 weeks from baseline for each endpoint.

\begin{tabular}{lcccc}
\hline & \multicolumn{5}{c}{ Score changes at 12 weeks from baseline } \\
\cline { 2 - 5 } & $\mathrm{N}$ & LS Mean & SE & $P$ value \\
\hline MDS-UPDRS Part 1 & 11 & -6.0 & 1.3 & $0.0009^{*}$ \\
MDS-UPDRS Part 1.2 & 11 & -2.4 & 0.2 & $<0.0001^{*}$ \\
MDS-UPDRS Part 2 & 11 & 0.2 & 1.5 & 0.9045 \\
MDS-UPDRS Part 3 & 11 & -5.1 & 0.9 & $0.0002^{*}$ \\
MDS-UPDRS Part 4 & 11 & -0.2 & 0.1 & 0.0668 \\
Motor symptoms & & & & \\
Tremor & 11 & -3.7 & 0.4 & $<0.0001^{*}$ \\
Rigidity & 11 & -0.8 & 0.3 & $0.0308^{*}$ \\
Bradykinesia & 11 & -0.4 & 0.2 & $0.0412^{*}$ \\
PIGD & 11 & -0.5 & 0.3 & 0.1911 \\
BDI-II & 11 & -1.2 & 1.9 & 0.5578 \\
JESS & 11 & -1.7 & 1.6 & 0.2925 \\
MMSE & 11 & -0.6 & 0.3 & 0.1467 \\
\hline
\end{tabular}

*: $P<0.05$ (vs. baseline) calculated with a mixed-effect model for repeated measures. BDI-II, Beck Depression Inventory-II; JESS, Japanese version of the Epworth Sleepiness Scale; LS mean, least-squares mean; MDS-UPDRS, Movement Disorder Society-Unified Parkinson's Disease Rating Scale; MMSE, Mini-Mental State Examination; PIGD, postural instability and gait disturbance; SE, standard error.

のスコア変化量は Supplementary Table 1 に示す.

その他, BDI-II, JESS, MMSE, それぞれのスコアは有意 な変化を示さなかった (Table 2). BDI-II, JESS, MMSE, そ れぞれの下位項目のスコア変化量は Supplementary Table 2 4 に示す.

\section{3 安全性評価}

有害事象「気管支炎」が 1 例 1 件発現（試験薬との因果関 係なし）し，重篤な有害事象，中止に至った有害事象は認め られなかった。

\section{4. 考察}

本研究は, 幻覚・妄想の軽減と運動症状の維持を同時に行 う治療方法の探索を目的に実施し，幻覚・妄想を発現してい る PD 患者に DAの減量・中止と同時にゾニサミドを新たに 追加することにより, 幻覚・妄想及び運動症状が改善した結 果が得られた。 ベースライン MDS-UPDRS Part 1.2 及び Part 3 の平均スコアがそれぞれ $2.7 \pm 0.5,31.5 \pm 7.2$ であったこと から考えると, 対象者は軽度から中等度の幻覚を発現し, か つ運動症状の治療が不十分な PD 患者と考えられた。また， 追加解析で示されたベースラインでの平均レボドパ用量は $354.5 \mathrm{mg}$, 平均 1 日レボドパ換算量 (levodopa equivalent daily dose, 以下 LEDD と略記） 19) は $764.9 \mathrm{mg}$ であり，これは日 本の診療実態 20) と比較してレボドパ用量は少なく, LEDDは 高い傾向を示した。追加解析により算出した，レボドパ，
LEDD 及び DA のベースライン及び 12 週後の平均用量を Supplementary Table 5 に示した.

幻覚・妄想の改善は，作用メカニズムからはゾニサミドが その原因とは考えにくいため,「DA 減量・中止」が主な原因 と考えられた。本研究の対象者は著者が幻覚・妄想の発現あ るいは悪化の原因として DA が最も可能性が高いと考えた患 者であることから，幻覚・妄想の改善は妥当な結果であり， 改めて幻覚・妄想の原因が何であるかを正確に見立て，その 原因への対処（原因が薬剂であると考えられる場合は減量・ 中止）することが重要であると考えられた.

本研究では, 上述の幻覚・妄想の改善に加え, 運動症状も 改善し, また, ADL 低下及び wearing-off 現象の悪化も認めら れなかった。よって，DAの減量・中止を行ったにもかかわ らず，ゾニサミドを追加することで運動症状がコントロール できたと考えられた。追加解析の結果, 平均 LEDD はべース ライン時 $764.9 \mathrm{mg}$ から, 12 週後 $585.8 \mathrm{mg}$ に減少し, これは DA 減量・中止による変化であった。ゾニサミドの LEDDの 報告はないものの, 今回の結果ではゾニサミドの追加により 平均約 $180 \mathrm{mg}$ LEDD の DA を減量することができた。なお， ゾニサミドの LEDD を導き出すためには, 複数の研究結果を 元とした詳細な検討が必要である。

各運動症状では，運動緩慢，振戦及び筋強剛のスコアが低 下し, 姿勢保持障害・歩行障害のスコア変化は認められなかっ た.よって、いずれの運動症状もゾニサミド追加により改善 し, あるいは悪化することなく, 各運動症状がコントロール できていたと考えられた。また，これらの運動症状のうち， 
筋強剛や運動緩慢のスコア変化は大きくなかったのに対し, 振戦のスコア変化は大きく, 特に姿勢時振戦のスコア低下が 顕著であった（Supplementary Table 1)。これは，前治療によ り残存していた姿勢時振戦が、ゾニサミドにより改善したと も考えられた，姿勢時振戦はレボドパの反応性が低いとの報 告 ${ }^{21)}$ があることから,ゾニサミドによる姿勢時振戦の改善に は, ドパミン補充療法とは違う非ドパミン系の作用が関与し ているのかもしれない

本研究では，幻覚・妄想が発現したPD 患者を対象とした にもかかわらず，ゾニサミドによる精神症状に関する有害事 象は認められなかった。 DA 減量・中止の影響を差し引いて 考えなければならないものの, ゾニサミドは幻覚・妄想を悪 化させるリスクは少ないと考えられた，更に，BDI-II，JESS 及びMMSEの評価結果から，ゾニサミドはうつ症状，眠気， 認知機能に対しても悪影響を与えないと考えられた。なお， 本研究において DA の離脱症候群は認められず，主治医が患 者の症状変化に注意を払いながら DAの減量・中止を行った ことがその理由と考えられた。いずれにしても，今回のよう な DAの減量・中止を行う際は離脱症候群の発現に注意を払 い対処すべきである。

本研究には限界が複数存在する。（1）選択バイアスとし て，対象者に適格基準を設けたため本研究に登録できる患者 のみが対象であったこと，及び単施設での実施であったこと。 (2) 試験薬投与期間が 12 週間と短期間であったこと。（3） 試験デザインがシングルアームであり, 対照群を設定しなかっ たこと．（4）対象者は大部分が女性であり，男性は 1 例のみ であったこと，本研究の結果は，これらの限界を考慮した上 で評価する必要があり, 今後の検討として対象者を増やした 長期間の評価等が必要と考えられる。

以上により，幻覚・妄想への対処として DAの減量・中止 した時のゾニサミド追加療法は，PD患者の精神症状及び運 動症状のコントロールに有用な戦略になる可能性があると考 えられた

Supplementary Table 1: Change in MDS-UPDRS item score from baseline

Supplementary Table 2: Change in BDI-II item score from baseline

Supplementary Table 3: Change in JESS item score from baseline

Supplementary Table 4: Change in MMSE item score from baseline

Supplementary Table 5: Dose of combined medications

謝辞：本研究にご協力いただきました患者様，ご家族の皆様に深謝い たします。また，本稿執筆にあたり，大日本住友製薬株式会社及び $\mathrm{EP}$ クルーズ株式会社よりメディカルライティングに関する支援を受 けました
※本論文に関連し，開示すべき COI 状態にある企業・組織や団体 本研究は大日本住友製薬株式会社が資金提供を行い実施した。ま た，大日本住友製薬株式会社は研究計画立案に参加したが，データの 管理，モニタリング，統計・解析及び監査には関与しなかった，丸山 秀徳は大日本住友製薬株式会社の社員である。

\section{文献}

1）「パーキンソン病診療ガイドライン」作成委員会編．パーキ ンソン病診療ガイドライン 2018. 東京：医学書院；2018.

2) Chaudhuri KR, Healy DG, Schapira AH. Non-motor symptoms of Parkinson's disease: diagnosis and management. Lancet Neurol 2006;5:235-245.

3) Santos-García D, de la Fuente-Fernández R. Impact of nonmotor symptoms on health-related and perceived quality of life in Parkinson's disease. J Neurol Sci 2013;332:136-140.

4) Obeso JA, Rodriguez-Oroz MC, Chana P, et al. The evolution and origin of motor complication in Parkinson's disease. Neurology 2000;55:S13-S20.

5）日本老年医学会, 日本医療研究開発機構研究費 ·高齢者の薬 物治療の安全性に関する研究研究班編. 高齢者の安全な薬物 療法ガイドライン 2015. 東京：株式会社メジカルビュー社； 2015.

6) Murata M, Hasegawa K, Kanazawa I, et al. Zonisamide improves motor function in Parkinson disease: a randomized, double-blind study. Neurology 2007;68:45-50.

7) Murata M, Hasegawa K, Kanazawa I, et al. Randomized placebo-controlled trial of zonisamide in patients with Parkinson's disease. Neurol Clin Neurosci 2016;4:10-15.

8) Murata M, Hasegawa K, Kanazawa I, et al. Zonisamide improves wearing-off in Parkinson's disease: a randomized, double-blind study. Mov Disord 2015;30:1343-1350.

9) Murata M, Odawara T, Hasegawa K, et al. Adjunct zonisamide to levodopa for DLB parkinsonism: a randomized double-blind phase 2 study. Neurology 2018;90:e664-e672.

10) Murata M, Odawara T, Hasegawa $K$, et al. Effect of zonisamide on parkinsonism in patients with dementia with Lewy bodies: a phase 3 randomized clinical trial. Parkinsonism Relat Disord 2020;76:91-97.

11) Okada M, Kaneko S, Hirano T, et al. Effects of zonisamide on dopaminergic system. Epilepsy Res 1995;22:193-205.

12) Sonsalla PK, Wong LY, Winnik B, et al. The antiepileptic drug zonisamide inhibits MAO-B and attenuates MPTP toxicity in mice: clinical relevance. Experimental Neurology 2010;221: 329-334.

13) Murata M. Novel therapeutic effects of the anticonvulsant, zonisamide, on Parkinson's disease. Curr Pharm Des 2004; 10:687-693.

14) Suzuki S, Kawakami K, Nishimura S, et al. Zonisamide blocks T-type calcium channel in cultured neurons of rat cerebral cortex. Epilepsy Res 1992;12:21-27.

15) Yang $\mathrm{YC}$, Tai $\mathrm{CH}$, Pan MK, et al. The T-type calcium channel as a new therapeutic target for Parkinson's disease. Eur J Physiol 2014;466:747-755

16) Schauf CL. Zonisamide enhances slow sodium inactivation in Myxicola. Brain Res 1987;413:185-188. 
17) Yamamura S, Ohoyama $K$, Nagase $H$, et al. Zonisamide enhances delta receptor-associated neurotransmitter release in striato-pallidal pathway. Neuropharmacology 2009;57:322-331.

18) Rascol O, Brooks DJ, Melamed E, et al. Rasagiline as an adjunct to levodopa in patients with Parkinson's disease and motor fluctuations (LARGO, Lasting effect in Adjunct therapy with Rasagiline Given Once daily, study): a randomised, doubleblind, parallel-group trial. Lancet 2005;365:947-954

19) Tomlinson CL, Stowe R, Patel S, et al. Systematic review of levodopa dose equivalency reporting in Parkinson's disease. Mov Disord 2010;25:2649-2653.

20）藤本健一, 村田美穂, 服部信孝ら. 大規模患者調査で明らか になったパーキンソン病の薬物治療の実態—2008 年と 2013 年の大規模患者調査結果の比較。Brain Nerve 2016;68: 1087-1098.

21) Dirkx MF, Zach H, Bloem BR, et al. The nature of postural tremor in Parkinson disease. Neurology 2018;90:e1095-e1103.

Abstract

\title{
Effects of switching from dopamine agonists to zonisamide on psychiatric and motor symptoms in patients with Parkinson's disease
}

\author{
Takashi Abe, M.D., Ph.D. ${ }^{1)}$ and Hidenori Maruyama, MSc. ${ }^{2)}$ \\ 1) Abe Neurology Clinic, Iwate, Japan \\ 2) Medical Affairs, Sumitomo Dainippon Pharma Co., Ltd., Tokyo, Japan
}

In 11 patients with Parkinson's disease (PD) who were using levodopa and had hallucinations and/or delusions considered to be attributed to use of dopamine agonists (DAs), we reduced or discontinued DAs and added zonisamide, and we then evaluated the effects of this treatment on psychiatric and motor symptoms. As a result, changes in the Movement Disorder Society-sponsored revision of the Unified Parkinson's Disease Rating Scale Part 1.2 (Hallucinations and Psychosis) and Part 3 (Motor Examination) scores 12 weeks from baseline were $-2.4 \pm 0.2$ and $-5.1 \pm 0.9$ (leastsquares mean \pm standard error), respectively, with the score reductions being statistically significant. These results indicated that zonisamide switching therapy is a useful strategy for managing psychiatric and motor symptoms in patients with PD when DAs are reduced or discontinued to avoid the onset or exacerbation of hallucinations and delusions.

(Rinsho Shinkeigaku (Clin Neurol) 2021;00:000-000)

Key words: Parkinson's disease, zonisamide, dopamine agonist, hallucinations/delusions, motor symptoms 